\title{
CULTURE
}

@

\author{
Natalia Dziewięcka \\ Maria Curie-SkŁodowska University (UMCS) in Lublin \\ dziewiecka.natalia@gmail.com
}

\section{Larry Flynt as a Controversial Advocate for Freedom of Speech in The People vs. Larry Flynt}

\begin{abstract}
The focus of this article is to examine the notion of freedom, and more precisely freedom of speech, in the light of The People vs. Larry Flynt. The analysis will pay close attention to what has always been a central concern of American society constituting one of the basic principles on which the new nation was founded. What is more, the article will try to indicate that freedom of speech has been as essential as controversial in many respects, which is proven by numerous examples from American history. As a baseline of this study I have chosen Larry Flynt, whose life and legal battles form the central theme of the selected biopic.

The article will scrutinize the plot of the movie, as it provides interesting insights into the life of this controversial advocate of freedom of speech. Flynt made himself well-known, if not notorious, by being the focal point of countless debates that concerned moral issues, public taste, and two basic rights guaranteed by the Declaration of Independence and the First Amendment.

Ultimately, the article will try to challenge the concept of a society based on the notion of freedom of speech by asking and trying to answer three questions: What precisely is freedom of speech? Is freedom of speech absolute? Are there any limits of expression and if so, then where to draw the line?
\end{abstract}

Keywords: freedom of speech, Larry Flynt, Declaration of Independence, The Bill of Rights, freedom of expression, boundaries of freedom

1 A shortened version of a thesis written under the supervision of Dr. Edyta Frelik and presented as a partial fulfillment for the degree of Bachelor of Arts at the Maria Curie-Skłodowska University in Lublin in 2015 


\section{The development of the idea of freedom in America}

New settlers came to America in search of freedom and liberty. Those two concepts prevailed in their mindsets when they chose to immigrate to the New World, which they hoped would assure endless opportunities for those who found their individualism to be a barrier making it impossible to live in any other environment. Having been persecuted in England, the Puritans' main goal was to create a place where they could freely practice their religious beliefs. Nevertheless, through the decades the concept of freedom appeared vague to everybody concerned. The reality in the colonies was rather that of discrimination, oppression, and even bloodshed for those who were unwilling to conform to the Puritan lifestyle. The system that had been allegedly constructed on the grounds of freedom, divested people of their right to voice their own thoughts.

One exception that was a haven for liberty was a Quaker colony, Pennsylvania, founded by William Penn. As one of the first advocates of democracy and religious freedom for all, he managed to safeguard the rights of American Indians and, through treaties, to create a society in which the two nations lived side by side. On the other hand, even there one could encounter instances of censorship, mainly in the sense that "printing was strictly regulated." In 1683, Penn presided over a council meeting during which "it was ordered that the laws of the colony should not be printed." Due to this prohibition, William Bradford, a colonial printer, was sentenced to one year in prison for printing "a pamphlet ... which was a copy of the colony's charter." This case marked itself in American history as "the first criminal trial ... involving freedom of the press" (Downs 1970, 11).

Another attempt at setting boundaries to freedom of expression took place in "the era of Comstock in 1868." A young man named Anthony Comstock began a "crusade against what he considered indecent literature." His organization was given a right to "search, seizure, and arrest" (Downs 1970, 16) people who did not conform to new suppressions. What is more, in 1873 the "Comstock Law," a federal obscenity law, was introduced. It is often referred to as the "Act of the Suppression of Trade in, and Circulation of, Obscene Literature and Articles of Immoral Use" (Downs 1970, 16). It stated that it was forbidden to mail "allegedly obscene publications." The word "allegedly" is crucial in this case because there was no specific method of distinguishing between what is obscene and what is not. Therefore, with "the growth of liberal thought, by changing literary taste, and by certain landmark court decisions," this law was "discredited by ridicule" (Downs 1970, 16).

Many years had passed, before three documents, crucial for American nation, changed the perception of liberty in the eyes of numerous people living in the New World. It was not until the end of the American Revolution when the ideas of equality and freedom (unfortunately they did not yet refer to women and slaves, emerged as lifeblood rights in all colonies. They were fundamental for Thomas Jefferson when he drafted the Declaration of Independence, as well as for James Madison, when he wrote the First Amendment. Those two documents, as well as the Constitution, were created 
by spokesmen of democracy who in every way were "educated, highly literate, and widely-read ... intimately acquainted with centuries of struggle between tyranny and freedom that had been going on in England and more recently in America" (Downs 1970, 12). Therefore, from the start they shaped ideals on which the new country was to flourish independently from influences from other nations.

The most cherished and praised words from the Declaration of Independence ensure one's widely understood concept of freedom, stating:

We hold these truths to be self-evident, that all men are created equal, that they are endowed by their Creator with certain unalienable Rights, that among these are Life, Liberty and the Pursuit of Happiness.

This passage and new principles that followed conveyed the idea of the new country that would be home to equal people who would collectively create a modern society. In reality, however, these words seemed rather ambiguous and meant different things to different social groups as they might have been interpreted in many ways. On that account, many amendments were passed in order to protect and refine the newly established law. The First Amendment, which was adopted in 1791, as a part of the Bill of Rights, guaranteed freedom of religion, expression, assembly, and the right to petition. James Madison stated in it that:

Congress shall make no law respecting an establishment of religion, or the press; or the right of the people peaceably to assemble, and to petition the Government for a redress of grievances.

With these words the most evident and secure rights of a person in the United States are to be protected. However, it is crucial to understand that the Bill of Rights was written for the federal government and that meant in general that in many cases federal laws were not incorporated into state laws. It was not until the $14^{\text {th }}$ Amendment was passed and a constitutional doctrine of selective incorporation was introduced when it was assured that states cannot enact laws that take away the constitutional rights of American citizens that are enshrined in the Bill of Rights.

The First Amendment has been a subject of ongoing debates, which concerned boundaries of freedom of speech. They have revolved around the question of if, how and in which cases the government can interfere with the press, so that it would not be considered a violation of rights. Miloš Foreman, the director of The People vs. Larry Flynt, presents a radical interpretation of one of the Founding Documents of the United States in an interview for Cineaste:

The Founding Fathers were so wise in the way they formulated the First Amendment. There will be no law abridging freedom of speech and freedom of expression. It is so clean and simple. If they wanted to add some loopholes, it would have been very easy, but obviously, they knew why they formulated it the way they did. (Porton 1997, 32) 
His view on this subject has appealed to a considerable number of American citizens but has also sparked heated debates on numerous occasions. Many reject censorship completely while others claim that in order for a society to function properly, some restrictions must be imposed. Some interpretations of the First Amendment have spawned actions which attempted to define clear limits to laws concerning freedom of speech. As one can read in a study conducted by Congressional Research Service, "[t]he Supreme Court has identified categories of speech that are unprotected by the First Amendment and may be prohibited entirely" (Ruane 2014, 1). They refer to those which include obscenity, child pornography, "fighting words," "true threats," incitement, and also instances of offensive speech. Nevertheless, in many instances efforts were made to ensure that freedom of expression would not be oppressed. For example, in 1919 Supreme Court Justice Oliver Wendell Holmes introduced "'a clear and present danger' test, according to which liberty of press and speech would remain unrestricted as long as public safety was not imperiled" (Downs 1970, 15).

\section{Significance of The People vs. Larry Flynt in the Debate over Freedom of Speech in the 1990 s}

Throughout U.S. history, the debates on the boundaries of freedom of speech have continued. They became even greater in the 1990s with the invention of the Internet. Owing to this innovation, people could voice their even most controversial opinions anonymously. The newfound freedom that the Internet gave to the public appeared to be a blessing to many and seemed a threat to others because it made it more difficult to set limits to its content. Consequently, the 1990s is one of the most diversified decades in terms of opinions about whether the authorities should interfere in the right of citizens to express their views.

It was then that a phenomenon called "culture war" (Hunter 1991) polarized America. It referred to

cultural issues touching on family and religious values, feminism, gay rights, race, guns, and abortion had redefined American politics. Going forward, bitter conflicts around these issues would be the fulcrum of politics in a polarized nation. (Ruy Teixeria 2009)

No wonder that Foreman decided to direct a movie about an extremely controversial advocate of freedom of speech, Larry Flynt, in that particular decade. Having been described as "oscillat[ing] between two classical American film genres: biography and court drama," (http://milosforman.com/en/movies/the-people-versus-larry-flynt) The People vs. Larry Flynt perfectly catered to the interests of moviegoers from the 1990s as well as to the interest of both Foreman and Flynt.

The cinematic portrayal of Flynt's life and legal battles can also serve as a perfect example of how Hollywood transformed the publisher of a hard-core porn 
magazine into "a free speech hero." His controversial path to success seemed to be of interest to the society at that time. The movie touches upon the controversial subject matter relating to pornography and obscenity. According to St. James Encyclopedia of Popular Culture, for many decades,

a small group of morally superior people were capable of setting the standards of what was obscene for their social inferiors. [However,] such a standard may have made sense within a rigidly defined social and class structure, but it ran counter to the very freedoms on which the American democracy was based, savaged the First Amendment, and abridged both the letter and spirit of the Constitution as a whole. (Jon Griffin Donlon 2000, 93)

Therefore, even though the content of the movie is controversial and many despised the idea that one group can interfere in others' fundamental rights, a large number of American citizens cheered for Flynt because he had been associated with an everyman who fights for the freedom of expression.

The message of The People vs. Larry Flynt was very significant for Americans also because "[t]he rise of the Internet in the 1990s added new fuel to the debate over pornography" (Donlon 2000,96) and consequently to the debate about freedom of expression. Having been faced with measures taken by authorities to impose fines for posting indecent language on the Internet, many once again started to question if and how the government should restrict citizens' rights guaranteed in the First Amendment. As one can read in the interview for $B O M B$ magazine:

With the fate of the Communications Decency Act [of 1996] - declared unconstitutional by a three-judge court — pending, and censorship, actual and implied, threatening the untrammeled exchange of protected speech on the Internet, the film's release couldn't be more timely. (Donlon 2000, 96)

The attempt to introduce an amendment to a bill in Congress which would ultimately result in censoring the content of the Internet by the government outraged the public and spawned a wave of protests. It also showed how fragile the concept of the freedom of speech is.

What is more, it is worth mentioning that, as Kathryn H. Fuller $(1997,1186)$ puts it in her review of Forman's movie, "the critical reception surrounding the film makes for a fascinating case study of cultural controversies about sexuality and gender politics in American society in 1990s." Those controversies had begun even before The People vs. Larry Flynt was released. Its scandalous poster featuring the main character "posing like Jesus on the cross, nestled between a woman's legs ... was, quite ironically, considering it's a film about censorship, banned only in the U.S. by the MPAA" (http:// www.thefrisky.com/photos/7-movie-posters-banned-for-being-too-sexy/banned_posters_larry/). Needless to say, the movie quickly became the topic of heated discussions, not only because of the contentious subject matter, but also because of the way in 
which it "airbrushes the contents of Hustler" (Porton 1997, 28) as well as the figure of its publisher. It depicts controversies that surround Flynt's (Woody Harrelson) professional life in pornographic business as well as his personal life - especially his marriage to Althea (Courtney Love).

The opening scenes briefly address Flynt's poor childhood, as well as his entrepreneurial skills as displayed by examples of him successfully selling alcohol to neighbors. Then, it moves on to focus on the emergence of a pornographic empire, beginning with a financially struggling strip club and ending with the success of Hustler magazine, which brought a fortune to its publisher. More importantly, however, the movie centers on Flynt's numerous encounters with the law. Viewers learn that he "has devoted his life to making money in the sex industry and to engaging in shocking and distasteful behavior" (Lucas 2007, 23). One of the most controversial publications is Hustler's advertisement parody of Campari Liqueur issued in the form of an interview with Jerry Falwell, a Fundamentalist minister and a man who "constantly sought ways to press his religious and political beliefs in any and all available media outlets." The parody featured a story suggesting that the minister is "a drunken hypocrite who [was] in sexual relations with his mother" (Lucas 2007, 22). Falwell reacted by

filing a $\$ 45,000,000$ federal lawsuit against Flynt and Hustler. [He] passed three theories: first, he claimed invasion of privacy, i.e., his name and likeness were wrongly appropriated for advertising or trade without his consent; second, he asserted a defamation claim of libel; and third, he claimed intentional infliction of emotional distress. ${ }^{2}$

Interestingly enough, Flynt responded in a counter lawsuit claiming that the minister had "infringed on Flynt's copyright of the ad parody" (Lucas 2007, 24-25) by xeroxing and distributing it.

Forman's cinematic portrayal of Flynt emerges as an unconventional but at the same time a significant voice in the debates about freedom of the press. This status is not shaken even by his controversial lifestyle, outrageous actions (for example showing up in court wearing the U.S. flag as a diaper) and a career in a pornographic industry. All this departs to a great extent from what one would expect of a true statesman fighting for the rights of an average man in society.

The movie portrays Flynt's alleged patriotism as well as his unusual way of fighting for freedom of the press. After being released from prison (he was charged with promoting obscenity in Hustler and therefore with engaging in organized crime), Flynt starts a free-speech campaign by first arranging a convention for free press. Then, Flynt

2 In legal terms, "intentional infliction of emotional distress or mental distress is a tort claim for intentional conduct that results in mental reaction such as anguish, grief, or fright to another person's actions that entails recoverable damages." "Infliction of Emotional Distress Law \& Legal Definition Intentional," US Legal, accessed on April 3, 2015, http://definitions.uslegal.com/i/ intentional-infliction-of-emotional-distress/. 
(surrounded by American flags and a crowd of people holding banners which read "Americans for free press") emerges on the stage announced as "the freedom fighter." His speech revolves around the notion of obscenity. He tests one's moral boundaries by challenging one's views on pornographic images and juxtaposing them with those depicting horrors of wars. By stating, "I think the real obscenity comes from raising our youth to believe that sex is bad and ugly and dirty, and yet it is heroic to go spill guts and blood in the most ghastly manner in the name of humanity," Flynt emerges as a voice of conscience (even for those who do not fully agree with his ideas) which seems to unveil the ambiguity of the concept. The notion of obscenity here is not associated with pornography but rather it is equated with society's unaccountable approval and consent to the horrific aftermaths of wars.

Flynt manages to influence not only his closest surroundings also to raise controversy throughout the United States. He provides the media with an FBI surveillance tape featuring John DeLorean (the corporate leader at General Motors and founder of the DeLorean Motor Company) being arrested for alleged major cocaine trafficking. Flynt does it only to, as he puts it, "shake up the system" and to provoke a situation in which he could pull all the strings. This case becomes ever so shocking to the society not only because a prominent public figure has been charged with a serious offence, but also because Flynt refuses to reveal the sources of the recordings. He is called to the court and fined several times because of refusing to obey the authorities. Every time he is made to execute court's orders and testify, he replies that "it is [his] right under the freedom of the First Amendment to protect [his] sources." Flynt breaks every rule that should be respected when one is questioned by the court and he conforms to almost none of the court's decisions or prohibitions by deliberately disobeying the court's orders or by leaving the state of California when he is forbidden to do so. His provocative behavior aims at increasing the publicity around him and he takes extreme pleasure in the fact that he can manipulate the court and the media.

Most notably, however, Flynt's status as a controversial advocate for freedom of speech is emphasized by his shocking attitude towards the authorities. His "notorious courtroom stunts" (Lucas 2007, 25) not only serve as comic moments in the movie but, most importantly, show his unconventional method of fighting for freedom. He pushes the limits of long-established social norms by coming to court wearing a T-shirt with "fuck this court" message, throwing oranges at the judge or telling unreal stories under oath. Those outrageous acts of behavior, although presumably performed in the name of freedom, make many reconsider the justness of the idea of absolute freedom.

However, most striking is the fact that Flynt evokes such contradictory feelings. $\mathrm{He}$ is, on the one hand, a hero to those who cherish the rights guaranteed by the First Amendment, and on the other hand, he is an anti-hero in numerous social circles. To quote Rodney A. Smolla (2004, 60), his "magazine drew the ire of prosecutors, politicians, and civic and religious leaders all over the country, and Flynt found himself regularly prosecuted on obscenity charges." This claim is confirmed in the scene when after being shot, Flynt and his family and friends wonder who would try to assassi- 
nate him. His brother asks, "Who the hell would want to shoot you Larry?" and Flynt quickly responds by saying, "Who wouldn't want to shoot me Jimmy?" The group then enumerates such organizations as CIA (because Hustler assigned an award for finding the killer of J. F. Kennedy), KKK (due to the interracial photo spreads in the magazine), the mob, or the extreme Religious Right. To the list of Flynt's enemies one can add some groups of feminists who oppose the transformation of Hustler's publisher, a "pornographer ... into a First Amendment hero" because, as Laura Butterbaugh $(1997,1)$ observes in her article quoting Norma Ramos,

the real heroes of the First Amendment are those that have raised their voices $\ldots$ for the rights for instance, of working people to organize labor unions, anti-war activists working to build peace, or civil rights activists fighting for social justice and equality, to name but a few.

Feminists strongly disagee with "the double standard of a movie," which portrays a "transformation of a [as they claim - real-life] sleazy, abusive man into a hero and a patriot" (Butterbaugh 1997, 1). Because of the content of Hustler magazine and Flynt's controversial biography, Butterbaugh claims that feminists, including Tonya Flynt (Flynt's daughter), "see the movie as a vehicle to legitimize the objectification of women and to glamorize violence against women" (1) rather than a real life story of an advocate for the freedom of speech.

On the other hand, Flynt has many supporters. As one can read in Tory L. Lucas's $(2007,25)$ article,

[this] massive lawsuit against a magazine and its publisher over a parody of a public figure sent shockwaves through the first Amendment community [and] although very few organizations or individuals stood up publicly for Flynt's ad parody of Farwell, many organizations supported Flynt's Constitutional fight.

Just before the final battle in the Supreme Court, a journalist reporting the event enumerates, as she puts it "unlikely supporters" such as The New York Times, the American Newspaper Publishers Association and the Association of American Editorial Cartoonists. They believe that "the First Amendment protection of free speech was under attack and that is why they have to "support Flynt's Constitutional fight" (Lucas 2007, 25).

Court battles between the "preacher man" and the "self-proclaimed King of Porn" (Lucas 2007, 25) have resulted in pastor's initial victory. Even though "the jury found that no reasonable person could have understood the ad as meant to describe actual facts ... and, because the ad would not be understood as making factual allegations, it could not be 'libel' within the traditional legal meaning of that term." However, Flynt is found guilty of "intentional infliction of emotional distress" and Falwell was awarded in total $\$ 200,000$ in damages. However, when Flynt appeals to the Supreme Court, Falwell loses in a unanimous ruling. The jury agrees with Flynt's attorney, Allan Isaacman, who states that 
at the heart of the First Amendment is the recognition of the fundamental importance of the free flow of ideas, freedom to speak one's mind is not only an aspect of an individual liberty but is essential to the quest for truth and the vitality of society as a whole, in the world of debate about public affairs many things done with motives that are less than admirable are none of the less protected by the First Amendment.

Furthermore, Chief Justice William H. Rehnquist explains the verdict by stating that "graphic depictions and satirical cartoons have played a prominent role in public and political debate throughout the nation's history" (485 U.S. 46, 1988). Therefore, one can conclude that criticism of public figures should be protected by free speech even if one considers it to be offensive or scandalous.

\section{Conclusion}

To conclude, the concept of the freedom of speech has been present in American life from its beginnings. At the time when the First Amendment was adopted this founding idea seemed ambiguous and appealed only to a select group of citizens. It has been evolving across time, posing a challenge as to how one should understand and define this concept. Therefore, the U.S. Supreme Court's role was "to determine what exactly constitutes protected speech" (http://www.uscourts.gov/about-federal-courts/educational-resources/about-educational-outreach/activity-resources/what-does). That is precisely why almost every court's decision which deals with the issue of the boundaries of freedom of speech, is regarded as controversial. This subject matter became a source of inspiration for numerous filmmakers, including those who in The People vs. Larry Flynt tackle the outrageous life of the most controversial advocate of the First Amendment. Flynt's life is often portrayed, as Larry Karaszewski describes it, as one of "a quintessential American, in the sense that he was born in a log cabin, he became a self-made made multimillionaire, he got shot for what he believed in and he ran for president" (https://www.youtube.com/watch? $\mathrm{v}=\mathrm{TXhW} 1 \mathrm{~S} 3 \mathrm{xVwM}$ ). Still, for some, he is regarded as a patriot and an "unlikely Everyman of the 1970s and 1980s [who fights] for freedom of speech and expression," (Fuller 1997, 1186) for others he comes across as just a sleazy pervert who makes money on "a violent, misogynistic porn magazine" (Butterbaugh 1997, 1). However, his contribution to the debate about the dangers of censorship is undeniable. By watching his numerous battles with the law, one's idea of freedom is challenged when faced with a question if for the sake of freedom one should be able to accept the content of Hustler magazine and the outrageous antics of its publisher. Is it really that, as Flynt puts it in an interview, "the price we pay for freedom is toleration [and that] we have to tolerate 'Larry Flynts' in the world so that we can be free"? He goes further, saying that "freedom of the press is not the freedom for your ideas but the ideas you hate the most" (https://www.youtube. $\mathrm{com} /$ watch? $\mathrm{v}=\mathrm{TXhW} 1 \mathrm{~S} 3 \mathrm{xVwM}$ ). Whether one agrees or not, Flynt creates his image 
of, and in many respects is viewed as, a free speech activist. Due to the fact that he was an active participant in "a landmark first amendment battle," (Lucas 2007, 25) he is often invited to speak out publically when current and controversial issues about freedom of expression are addressed. Now these debates include controversies around such current events as the Charlie Hebdo shooting, the banning of an American political satire comedy The Interview due to terrorist attack threats from North Korea, and shooting at a Mohamed cartoon drawing contest in Texas. Having all this in mind, one can see the extent to which the issue of freedom of speech pervades the present-day world and how the character of Larry Flynt (even though controversial, outrageous and not accepted by many) with his fight for freedom of expression, may play an important role in today's reality.

\section{References}

"7 Movie Posters That Were Banned For Being Too Sexy.” The Frisky. Accessed June 1, 2015. http://www.thefrisky.com/photos/7-movie-posters-banned-for-being-too-sexy/banned_ posters_larry/.

Asimow, Michael, and Shannon Mader. Law and Popular Culture. New York: Peter Lang Publishing, 2013.

Butterbaugh, Laura. "Is This Freedom?” Off Our Backs: A Women's Newesjournal, April 1997. "Comstock Act: United States [1873]." Encyclopcedia Britannica. Accessed April 10, 2014. http://www.britannica.com/EBchecked/topic/130734/Comstock-Act.

Donlon, Jon Griffin. "Pornography." Edited by Tom Pendergast and Sarah Pendergast. St. James Encyclopedia of Pop Culture. Farmington Hills, MI: St. James Press, 2000.

Downs, Robert B. "Freedom of Speech and Press: Development of a Concept." Library Trends 19, no. 1 (July 1970).

Fuller, Kathryn H. "The People vs. Larry Flynt. by Oliver Stone; Milos Forman.” The Journal of American History, December 1997.

Hustler Magazine and Larry C. Flynt, Petitioners v. Jerry Falwell, 485 U.S. 46 No. 86-1278 (Supreme Court of United States 1988).

"Infliction of Emotional Distress Law \& Legal Definition Intentional." US Legal. Accessed April 3, 2015. http://definitions.uslegal.com/i/intentional-infliction-of-emotional-distress/.

Larry Flynt - Interview - Controversial 1996. Accessed January 6, 2015. https://www.youtube. $\mathrm{com} /$ watch? $\mathrm{v}=\mathrm{TXhW} 1 \mathrm{~S} 3 \mathrm{xVwM}$.

Lucas, Tory L. "Preacher Manv. Porn King: A Legal, Cultural, and Moral Drama Starring Jerry Falwell, Larry Flynt and the First Amendment." The Nebraska Lawyer, August 1, 2007.

Petersen, Jennifer. "Speech, Freedom, and the Political Imaginary in The People vs. Larry Flynt.” All Academic. Accessed April 22, 2015. http://www.allacademic.com/meta/p113217 index.html.

"Political Polarization in the American Public.” Pew Research Center, June 12, 2014. http:// www.people-press.org/2014/06/12/political-polarization-in-the-american-public/. 
Pobrane z czasopisma New Horizons in English Studies http://newhorizons.umcs.pl Data: 26/04/2023 15:19:20

Porton, Richard. "Porn Again: The People vs. Larry Flynt. An Interviev with Milos Forman." Cineaste Publishers, Inc. 22, no. 4 (1997): 28-32.

Ruane, Kathleen Ann. Freedom of Speech and Press: Exceptions to the First Amendment. Congressional Research Service, 2014. https://fas.org/sgp/crs/misc/95-815.pdf.

Smolla, Rodney A. "Amendment Martyr, First Amendment Opportunist: Commentary on Larry Flynt's Role in the Free Speech Debate." First Amendment Law Review, January 1, 2010.

Smolla, Rodney A. "Larry Flynt: Freedom of the Press." Edited by Melvin I. Urofsky. 100 Americans Making Constitutional History: A Biographical History. Washington: CQ Press, 2004.

“The People vs. Larry Flynt 1996.” Miloš Forman’s Official Website. Accessed March 25, 2015. http://milosforman.com/en/movies/the-people-versus-larry-flynt.

“What Does Free Speech Mean?" United States Courts. Accessed June 1, 2015. http://www. uscourts.gov/about-federal-courts/educational-resources/about-educational-outreach/activity-resources/what-does 